\title{
TÍTULO: Citizen participation in the digital public sphere in Cuba? Debate on constitutional reform in the digital forums of the news platforms Cubadebate and Oncuba
}

\author{
Luis Yaim Martínez Acebal B.J \\ Bachelor of Journalism from the Universidad Central Marta Abreu de Las Villas, in Santa Clara, Cuba
}

How to cite this paper: Luis Yaim Martínez Acebal B.J. (2019). TÍTULO: Citizen participation in the digital public sphere in Cuba? Debate on constitutional reform in the digital forums of the news platforms Cubadebate and Oncuba. The Educational Review, USA, 3(11), 175-186.

http://dx.doi.org/10.26855/er.2019.11.002

*Corresponding author: Luis Yaim Martínez Acebal B.J, Bachelor of Journalism from the Universidad Central Marta Abreu de Las Villas, in Santa Clara, Cuba. He is currently studying a Master's Degree in Communication at the Iberoamericana University Ciudad de México. My line of research is focused on communication and politics, based on the social changes that are taking place in Cuba.

Postal Address: Plomeros 24, 605 C, Colonia Morelos, Alcaldía Venustiano Carranza. Mexico City. Mexico City. ZIP Code: 15270. Mobile Phone: (+52)3310559595

Email: yaim.acebal@gmail.com

\begin{abstract}
Reflecting on a utopian system of political relationship between State and citizenship generates the fundamental debate of this article. In the following pages, reference is made to Cuba and its people, in a relationship that holds as a background the analysis of the link between government and electronic democracy, in a scenario dominated by the authoritarian discourse of the regime in power. The construction of a digital public sphere constitutes the motive for determining the existence of citizen participation in Cuban public space. The case study is the consultation and referendum of the Cuban Constitution, during 2018 and 2019, through two online news platforms: Cubadebate and OnCuba. This article emphasizes, through content analysis, the interdependence of these spheres in order to access a general perspective of the Internet impacts on politics, mainly in the Cuban context. Its main contribution is of a theoretical nature by highlighting the existence or not of a digital public sphere in Cuba.
\end{abstract}

\section{Keywords}

Citizen participation, digital public sphere, Cuban Constitution, authoritarian regime, Internet

\section{Resumen}

La reflexión sobre un sistema utópico de relación política entre Estado y ciudadanía genera el debate fundamental de este artículo. Dentro de las siguientes páginas se referencia a Cuba y a su gente, en una relación que tiene de trasfondo el análisis del vínculo entre gobierno y democracia electrónica, en un escenario dominado por el discurso autoritario del régimen en el poder. La construcción de una esfera pública digital constituye el móvil para determinar la existencia de la participación ciudadana en el espacio público cubano. El caso de estudio es la consulta y referéndum de la Constitución cubana, durante 2018 y 2019, a través de dos plataformas de noticias online: Cubadebate y OnCuba. Este artículo enfatiza, a través del análisis de contenido, en la interdependencia de estos ámbitos para acceder a una perspectiva general de los impactos de internet en la política, principalmente en el contexto cubano. Su principal contribución es de carácter teórico al poner en el relieve la existencia o no de una esfera pública digital en Cuba.

Palabras claves: Participación ciudadana, esfera pública digital, Constitución cubana, régimen autoritario, Internet.

\section{Introduction}

The debate on the impact and social uses of information and communication technologies (ICTs) in favor of processes that are configured in the public sphere has been marked by successive transformations, ranging from the most moderate optimism, sometimes fanatical, to the most irate pessimism, occasionally apocalyptic.

Today's society is characterized by a transformation of paradigms in which the non-stop interaction of its citizens and 
their respective networks through the media is fundamental. This leads to changes and social movements that attack, mainly, the existing power relations in society and its institutions, and look for circumstances that lead to transformation and creation of new prototypes of social structures.

According to Zelizer and Allan (2002) "given the global interconnection of the media, the public sphere has become increasingly integrated into a global society of networks, with new sub-national and supra-national coordinates, and consequently new players and alliances" (p.21).

Thus, today, when a government opens the doors to ICTs and expands its governmental interests to the network, the horizon for debate and deliberation in the public sphere is broadened, creating conditions conducive to the birth of a digital public space, where the character of the state is examined and promulgated under the constructive criticism of those who make use of these communication platforms.

The use of new information and communication systems is making it possible for governments, institutions and companies to hide less of their information, making them more open, more transparent. Because they compete more than in analogue times with private and personal information. (Ortega, 2019, p. 12)

Internet has become an essential tool to produce senses. In the case of Cuba, thanks to the opening to the digital world, we are witnessing a new moment or stage in communication, which, if we take advantage of its benefits, would represent the production of strategies for the appropriation of available technological resources. However, in particular, theoretical questions are being renewed about the behavior of this type of technology in the communicative practice of the island, both between people and between government, political and social institutions and the inhabitants themselves, which has already been the subject of successive debates, considered one of the dimensions of the so-called information society.

The recent constitutional referendum, held on February 24, 2019, was preceded by a wide-ranging debate in the Cuban public sphere. Through popular assemblies convened by the high political spheres of the country, an entire consultation process was developed that brought together the majority of the population living on the island. Through the tradition of plebiscites in Cuba, these meetings were held in the constituencies, which are the basis of the electoral system, and in the main workplaces.

But even so, there was a distinctive catalyst within this debate. An exercise that can be catalogued as sui generis, after the permanence of many Cubans in social networks and the encounter between two forms of thought so openly in conflict.

Even so, when the Internet made these questions visible, one might ask: what characteristics does the Cuban public sphere present? What conditions made possible the debate on the issues dealt with in the current Magna Carta from the appropriation of the Cuban digital space? Who appropriated that digital public space that is emerging on the island?

Bearing in mind the challenges posed by the previous questions, this article attempts to analyze the current debate and deliberation scenarios in Cuba, starting from the premise that as a result of the popular consultation carried out during the months of August to November and the period prior to the date of the popular referendum on February $24^{\text {th }}, 2019$, the Cuban public sphere became oversized and began to be the seat of new spaces for debate and deliberation, which impacted the way of communicating in the country, conditioned, until that date, only to the offline sphere.

To this end, we will conduct a theoretical review of fundamental authors on the public sphere, based on the Habermasian conception and the main criticisms and contributions they have made to their postulates, from liberal theories to assumptions that include totalitarian/authoritarian governments. And through this analysis we will apply the technique of quantitative data analysis to observe, compare, and establish distinctive margins for the Cuban public sphere.

We will take as case study Cubadebate, self-titled alternative medium that responds to the editorial policy of the Cuban government, and OnCuba, alternative medium financed from States United and with an important media impact in the Caribbean country, being the only media with these characteristics attached to the International Press Center ${ }^{1}$.

The article is structured in a section where the pertinent theory for the analysis to be made is gathered, as well as a methodological section, where the way of dealing with the matter is described, to finally offer the results and conclusions of the study. Annexes are included in order to show the dynamics of the process under study.

\footnotetext{
${ }^{1}$ The International Press Center (CPI) of the Ministry of Foreign Affairs of the Republic of Cuba is the institution in charge of attending to the communication generated at an international level from the island through the foreign correspondents accredited in the nation.
} 


\section{Context of the Case Study}

In Cuba, after more than 20 years of connection, the State can still determine who can access Internet, through a complex system of political-productive affiliation. In theory, "they tend to be officials of state institutions and companies, some professionals such as journalists, doctors, artists; people with a differentiated income, either because they work in the tourism sector or because they receive remittances from relatives living abroad" (Ramírez, Salgueiro \& Sá Martino, 2018, p. 420). One might think that in this way the criteria proposed on the Internet become uniform and mediated by this privileged condition. However, this is not so much the case.

According to the 2019 Digital Report of We Are Social and Hootsuite, Cuba ranks $16^{\text {th }}$ in the Internet growth ranking, with a relative increase of more than 27 percent, which means a total of six million 470000 users, for a $56 \%$ penetration, in a nation that has, according to the 2012 Population and Housing Census, 11.1 million inhabitants, most of whom connect from one of the country's 830 WIFI spaces.

The country also has a large number of emigrants, who from other latitudes participate, thanks to Internet, in what happens on the island, an issue that allows the link and minimizes the remoteness of the issues placed in the digital sphere, formed by the Cuban press media and the citizens themselves, from the growing access to social networks.

The opening of the country to $3 \mathrm{G}$ technology, in December 2018, also meant a substantial change in the whole communicative dynamic. Despite high prices compared to the average Cuban salary, access has been growing.

For the case of the constitutional proposal taken to discussion and popular vote, the variables were expanded and those who once needed to raise their hand to ask for the floor, made new accounts and began to write another story. Therefore, it is opportune the reflection that Carlos Manuel Álvarez subscribes from the Revolution 60 section $^{2}$.

What the government could not foresee when it called for the referendum - or perhaps it believed a lesser evil, and it has not been - was the substantial debate that seems to have taken place among the different civil society forces that have questioned or opposed the constitutional project. (Álvarez, 2019, p.1)

Something similar to what Yanina Welp conceived in her column Public Agenda of El País. The researcher states that "the dimensions of the participatory process would have exceeded the government's expectations, while the discussions that took place could also show an expectation of changes to which it would be difficult to respond at this time" (Welp, 2019, p. 1).

During the months preceding the voting and the days following the constitutional plebiscite, social networks and news platforms became a space for struggle, where \#YoVotoSí, \#YoVotoNo and \#YoNoVoto began to gain space in a country that is just beginning to have "massive" access to the Internet, after many years of disconnection.

For civil society actors around the world, digital media and online social networking applications have changed the way dissent is organized (Bimber, 2005; Howard, 2010; Still, 2005). And for Cuba, the presence and action of its political opponents in the network of networks was already an unavoidable scenario.

Although the yes reached a considerable majority, it was significant that the Constitution was not ratified by more than $10 \%$ of the voters and more than $20 \%$ of the electorate, in contrast to previous plebiscites marked by almost unanimity in the votes. It was a clear reference that times are changing and what happened on the Cuban digital stage played a crucial role.

\section{Of Social Networks, Spheres and Platforms}

The day after the voting in each Cuban polling station, life in the country continued its normal course. The hectic daily life of the Cuban won the pulse of a process that had structurally represented a change, both constitutional and at the level of social organization. What happened around the debate on the referendum on the Cuban Constitution has a lot of structural symbolism, as well as collective identity. By February $25^{\text {th }}, 2019$, it can be said that the Cuban public sphere had been complicit in a different kind of participation.

The yes, although majority, is uniform and monochromatic, and no one could find really significant differences between the convictions of one or another voter who has joined this current. No, on the other hand, is belligerent and diverse,

\footnotetext{
${ }^{2}$ Revolution 60 is a series that examines the six decades of the Cuban Revolution and is published by The New York Times. The section brings together writers, intellectuals, artists, protagonists, dissidents and supporters of the Revolution to discuss their role in the historical development of Latin America and its relations with the United States over the past 60 years.
} 
visibly rich in contradictions, and many Cubans arrived at that conclusion in very different ways. (Álvarez, 2019, p. 2)

The concept of public sphere originally developed by Jürgen Habermas (2014) is based on a historical reconstruction of modern society structured in successive phases. In a certain way, they can be grouped into a first pre-capitalist period, a second liberal capitalist and a third bourgeois and contemporary capitalist.

The term refers to "a common space in which members of society are seen to come together through a variety of media: print, electronic and also face-to-face, to discuss matters of common interest and thus to form a common front about them" (Taylor, 2004, p. 83).

Peter Dahlgren, on the other hand, points out that "in schematic terms, a functional public sphere is understood as a constellation of communicative spaces in society that allow the circulation of information, ideas, debates, ideally freely and also the formation of political will (i.e. opinion)" (2005, p.148).

However, returning to the vision of (re)construction, Habermas defines the public sphere as a social space for mediation between the state and the private sphere. His main interest is to understand the decadence of the liberal project of the nineteenth century, which had in the configuration of the liberal bourgeois public sphere, the constitution of civil rights that ensured the autonomy of the private sphere before state regulation.

In the influential formulation proposed by Habermas, the public sphere extends beyond institutional policies and, critically, is capable of generating fundamental challenges for that institutional framework (2009a). From this perspective, the public sphere provides an important source of emancipatory power to overcome unfavorable or unjust institutional policies.

The importance of the habermasian concept of the public sphere, however, is not limited to the fact that it makes it possible to understand the decadence of this project, but also constitutes a methodological framework for the social sciences and especially for the critique of ideology.

And although the theoretical anchorage of the public sphere varied simultaneously with the conditions of social development in practice, a respect for the original place conferred by Habermas was always maintained. Hence the implication and importance of understanding the place of the public sphere in the deliberative model of democracy from a broad reconstruction, because it allows to consider the intellectual project as a whole.

To this end, Nora Rabotnikof characterizes it as a "hinge between civil society and the State, and fundamentally as a space for political creation" (2010, p. 42). For it is there that the most important issues of political performance, economic outcomes and social development are developed.

Precisely the answers come, in many cases, through complex scenarios. The diversity of the public sphere is one of its most influential academic attractions. Each space takes on the form and nuances of the social and political structures within which it operates. This statement, as obvious and simple as it may seem in current rhetoric, has been regent in academic research on the links between political regimes and the public spaces they dominate.

Although the actions of the forces are divided and upset in a polarized world, all these expectations are based on the four basic categories noted by Gurevitch and Blumler (1995) and on the assumption that ideal democracy equals participatory democracy, where politically informed citizens deliberate and play an active role in government.

However, the specific function of the public sphere in a world divided into two fundamental extremes is mediated by a diversity of social, economic and political conditions that shape democracy and impact the actions of the actors involved within the limits of the created public space.

The assessment of this possibility is made in conjunction with citizens' contributions and their deliberative preferences. In theory, "any citizen could potentially be a contributor to the public sphere in the future" (Evans, 2012, p. 876), becoming an acute participant who contributes to the compilation of public talks or a non-participant who knows and listens to what others deliberate (Evans, 2012), in that "instance of open communication and public spirit", as described by Baiocchi (2003, p. 55). This situation agrees with the defining argument expressed by Eliasoph in writing that the public sphere "arises when people speak in public" (1998, p.16).

Thus, for many it is impossible to dissociate it from the dominant approach that the public sphere is the place where citizenship is exercised. Without caring that many acts defining citizenship, such as voting, are individual and carried out in secret (Adut, 2012).

Likewise, other visions transcend the legal scope and incorporate "the habits, feelings and values of individuals that 
are translated into specific practices", prescribing the existence of "a citizen who needs to be systematically involved in the public sphere, who must know not only how the system works but also how to insert and participate in it" (Country Report on Quality Citizenship, 2014, p.19).

And if public spaces require the permanence of a committed citizen, interested and able to belong to it. In digital scenarios, the frequency of intervention does not cease to be linked to these characteristics, although it acquires other dimensions and meanings. Therefore, the five sectors mentioned by Dahlgren (2005) can be related to define the public spheres in the network, which include:

1. E-government versions, usually top-down, where government representatives interact with citizens and where information about central administration and services is available.

2. The advocacy/activist domain, where discussion is framed by organizations with generally shared perceptions, values and objectives, and oriented towards forms of policy intervention.

3. The wide range of diverse civic forums where opinions are exchanged among citizens and where deliberation can take place. This is generally understood as the paradigm of the web version of the public sphere, but it would be quite wrong to neglect others.

4. The pre-political or parapolitical domain, which conveys social and cultural issues. It has to do with common interests and/or collective identities.

5. The mastery of journalism, which includes all of the major news organizations, which broadcast online.

According to these variants, and in conjunction with the different theoretical positions analyzed above, they are dominated by invariant spaces, which adduce spaces of ancient times without seeing the asymmetries that the world has adopted, and become blind and reluctant to recognize that there are other approaches, which have more to do with the type of regime in which the public sphere survives and which does not ignore the quality of citizen participation, nor the development of institutions and government in the public space of social interaction.

Rather, Alexander Dukalskis points out that "an active and vibrant public sphere in which citizens debate and question the actions of the state endangers the control of the power of authoritarian leaders because deliberation has an unpredictable quality" (2017, p. 26).

Indeed, these sharp divergences in the form and function of the public sphere in different political regimes are rooted in different normative paradigms of government accountability and scrutiny, political freedom, civic participation, and public election $^{3}$.

Now, within the contemporary perspective and analyzing the above, it is opportune to establish a comparison between both social configurations, therefore, "if an ideal democratic public sphere is one in which free political discussion can take place among citizens and critical information can circulate openly, an authoritarian public sphere approaches the opposite", subscribes Dukalskis (2017, p. 3-4).

For this author it is a field of discussion and political information that is dominated and manipulated by the authoritarian regime and/or its allies and that is characterized by the efforts of the state to establish its foundations, delineate its limits and monitor its content.

"The authoritarian public sphere is characterized by state repression and messages of legitimation manufactured by the state. The former works to ensure the effectiveness of the latter by amplifying pro-regime perspectives and marginalizing critical voices" (Dukalskis, 2017, p. 26).

In other words, the fundamental thesis of all this discussion is that of keeping citizens' voices silenced through strict censorship, repression of journalistic freedoms, and intense efforts to structure highly selective information flows for the general public (Mughan \& Gunther, 2000).

In this way, the right to deliberation is dented by the government's extreme vigilance over the public space of social and political debate. "An authoritarian public sphere limits political discussions, channels political imagination, atrophy political discourse and amplifies pro-regime voices" (Dukalskis, 2017, p. 4).

With these arguments, undoubtedly, Dukalskis becomes a proselyte of Habermas but, at the same time, a defiant of his conceptions, because, for him, following Habermasian logic, if a deliberative sphere is controlled and manipulated by

\footnotetext{
${ }^{3}$ See Siebert, Fred S., Theodore Peterson \& Wilburn Schramm (1956). Four theories of the press. University of Illinois Press, Estados Unidos: Urbana. 
an authoritarian state, it cannot be understood as a public sphere, however the authoritarian public sphere is a place dominated by the state, instead of a sphere that necessarily defies the state. "The device of the authoritarian public sphere draws attention to the state's efforts to delineate the limits of political discourse and manipulate its content to prevent the emergence of genuine and unrestricted public deliberation" (Dukalskis, 2017, p. 27).

The result is not an academic description of the public sphere, but an understanding of the processes that take place there, both in their democratic and authoritarian versions. And in that sense, the Internet also moves its tokens for or against public space.

Since its arrival, the Internet has been valued with a renewed spirit of socialization practices, but in authoritarian contexts it was seen as a danger to the integrity of governments. And while some took the lead, thanks to their economic power and vision of the future, others were left behind on the waiting list, claiming less penetration of foreign markets to their audiences. And this is because in practice,

the new media have the potential to catalyze collective protest (...) by reducing barriers to communication and organization of the opposition, contributing to information cascades, raising the perceived cost of repression by authoritarian rulers, and mobilizing international public opinion. (Dukalskis, 2017, p. 35)

That's how the Cuban public sphere worked until the awakening hit the face with a slap protected by years of technological backwardness and fear of innovation. The costs of precaution can be seen in a detailed popular outcry expressed openly.

Meanwhile, the present article does not fail to recognize the opportunities of each of the five elements raised by Dahlgren, observing his ability to schematically define how the digital public sphere is conceived, as well as the arguments put forward by Dukalskis, regarding the characteristics in authoritarian/totalitarian regimes, however, for research purposes, the main focus will be on the third point cited by Dahlgren, while we understand the digital public sphere respecting its configurative variants and see it as the public space where information, ideas and debates circulate, but in a scenario where the State delineates the limits of political discourse and manipulates its content to prevent the emergence of a genuine and unrestricted public deliberation.

\section{What the Cuban Digital Public Sphere Lets Us See After the Referendum from Cubadebate and Oncuba}

Referendums on ratification of constitutional reforms have been identified with mechanisms of democratic legitimation, although comparative politics shows that they have been as much, or more frequent in dictatorships as in democracies.

The dilemma is that the government, under the one-party manifesto, occupies public spaces without allowing an informed debate, and without strong resistance, due to the existence of an incipient Cuban civil society.

However, some organizations are working to counter this fact. With certain margins of freedom, they appropriated Cuban digital spaces and organized well-founded debates that show that a different Cuba "can be on the horizon of the possible" (Welp, 2019, p. 2).

The Cubadebate and Oncuba news platforms were the scenes of the intense campaign that both sides established in order to influence the electorate's vote. Through their online comments, Internet users were able to establish their points, doubts and concerns. During the period we have a total of 324 jobs in both news platforms, divided as follows: 70 published in Cuba, towards a new Constitution, from Oncuba and 254 in The Reasons for Cuba, edited by the Cubadebate platform. Data that allow us to cover the entire analysis period selected. However, from this sample, a selection is made, for analysis, of the works whose headings include the word Constitution, which reduces the size to 69 journalistic works and their comments included.

The purpose of this temporary cut is to seek the impact of the constitutional referendum process on the population connected to the Cuban digital public sphere and from there to know in which of the two media was discussed more and which of the issues brought to debate generated more discussion and criteria among Internet users.

In this sense, two fundamental aspects of the conversations articulated from the chosen comments were analyzed: a) Quality of the debate through reciprocity in the structuring of the discussion threads (messages that initiate or continue the debate, emergence and development of discussion nuclei, narratives of points of view); and b) The number of comments in the selected publications in one medium or another; where we value the influence of the medium and its acceptance among Internet users. 
Operationalization:

1. Comments written in Cubadebate:

1.1. Structuring the discussion thread

1.1.1. Messages initiating the debate

1.1.2. Messages continuing the debate

\subsubsection{Development of discussion}

\subsubsection{Point of view narratives}

1.2. Number of written comments per publication

\section{Comments written in OnCuba}

\subsection{Structuring a discussion thread}

\subsubsection{Messages initiating the debate}

2.1.2. Messages that continue the debate

\subsubsection{Development of the discussion}

\subsubsection{Narratives of points of view}

\subsection{Number of written comments per publication}

For this reason, the grouping of the texts has been elaborated, firstly and then the comments that appear there have been analyzed, in order to assess the quantity of elements to be taken into account for the analysis.

The questionnaires are applied based on the reference in the texts with comments and according to the amount of them within the work. The main difference is that the press, under the algorithms exposed for the analysis, shows significant differences with respect to OnCuba. However, all the articles published in OnCuba presented comments, unlike Cubadebate which was not entirely effective in mobilizing the word of its readers.

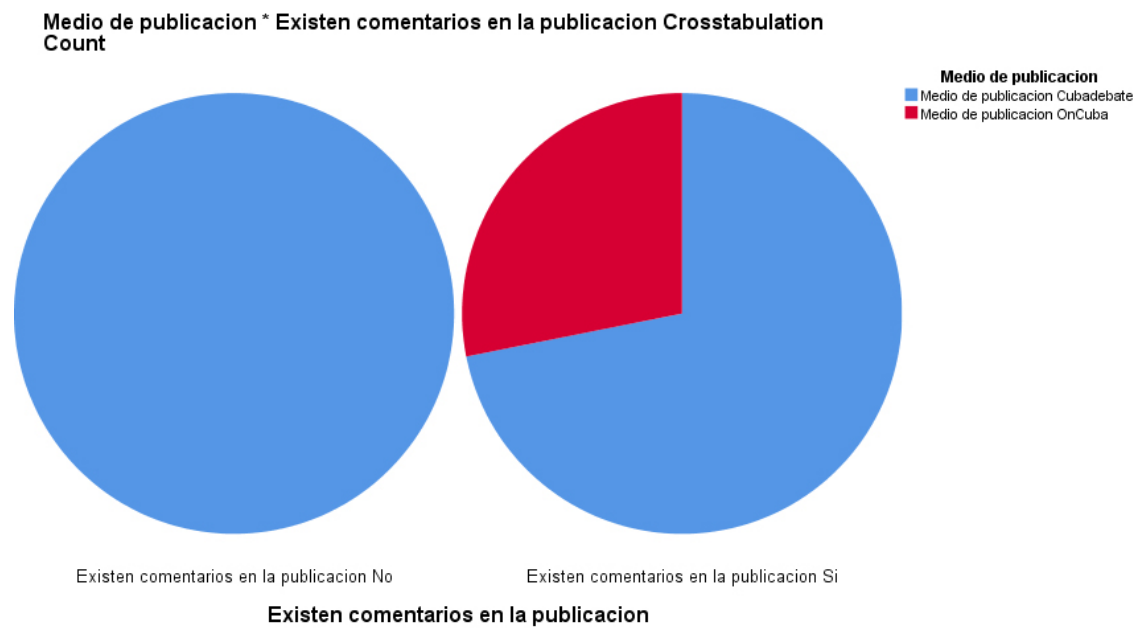

Of the total sample, $30.8 \%$ of the comments relate to the text to which they refer, i.e., that they show reader acceptance of the topics spoken of according to the constitution.

Finally, we completed the profile of the participating works with the data on the media responses to the comments, in order to see the institutional intervention in the debates of the public sphere and the hyperlinks that would allow access to works on the specific subject dealt with in the article, inside or outside the site, in both cases, the response is zero, because the two variables are related in both platforms and represent the same results, evidencing a way of acting, where the readers' voice is enhanced.

And in this sense, in order to review the themes that generated the most debate in each of the press media, we obtained that the predominance of other themes different from those exposed by the press media always qualified the debate on 
the net, marked by the context to which the work was exposed.

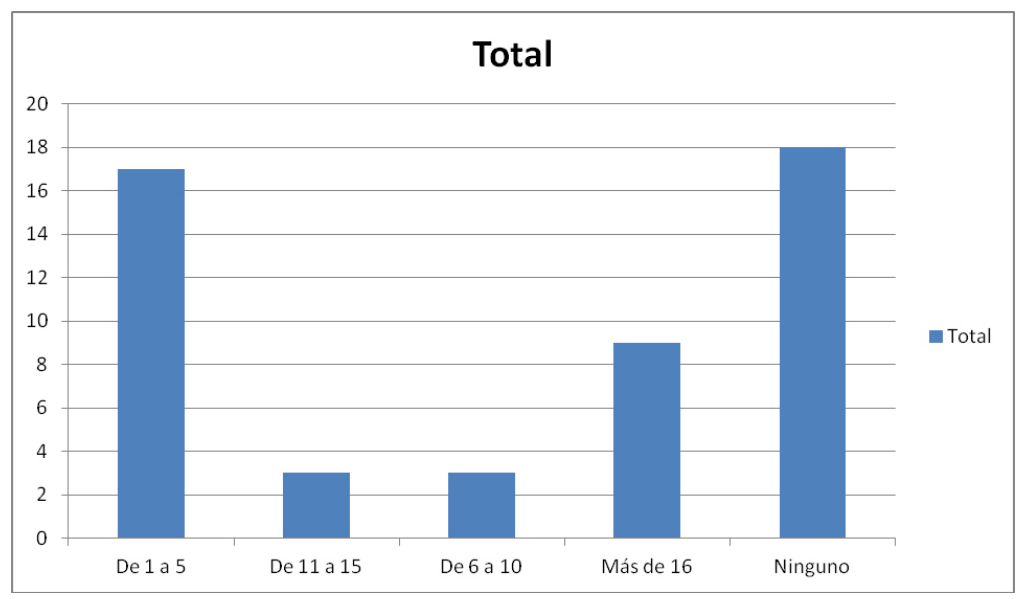

Medio de publicacion * Las tematicas sobre la constitucion reflejadas en los comentarios son: Crosstabulation

Count

as tematicas sobre la constitucion reflejadas en los comentarios son:

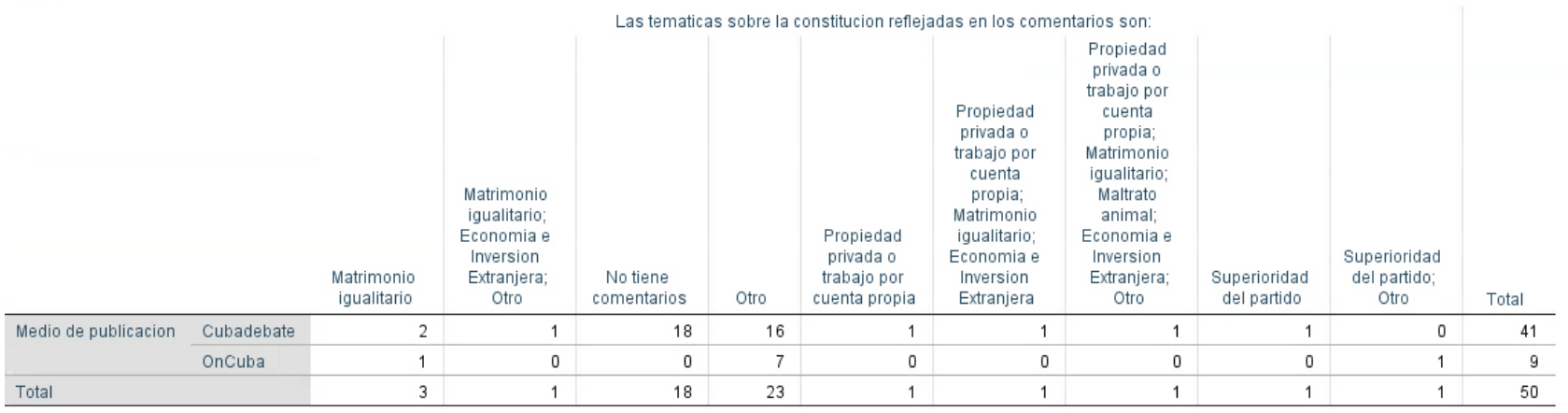

The analysis of the data obtained from the questionnaire helped us to describe citizen participation in the digital media OnCuba and Cubadebate during the constitutional referendum held in Cuba. We have structured the results in several sections: existence of comments, number of comments, relationship between comments and the topics most addressed in the comments.

The existence of comments in the two online media is considerable, which evidences the interest aroused by the subject in question and also the prestige achieved by the platform.

\section{¿Existen comentarios en la publicación?

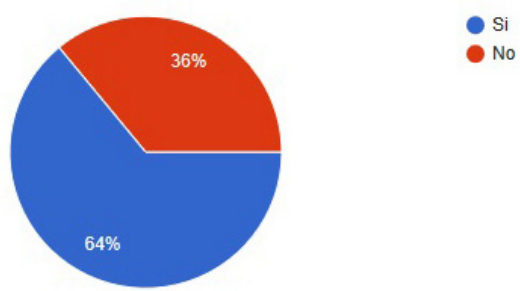

However, not all publications reflect the same popularity in terms of the existence of comments. For example, the greater frequency in the trend reflects $36 \%$ post-news preferences. The lowest rating in comments was 1 , with the highest rating marked at 16 and above, which was scored post with nearly 80 comments on the platform.

We then try to determine the themes proposed by the online press and their link to the debate among Internet users. Eight situations were proposed: No comments, party superiority, elections for president and prime minister, equal marriage, animal abuse, economy and foreign investment, in addition to the possibility of marking others and has no comments. Each of these possibilities was consulted and the results reflected were as follows: 
¿Cuántos comentarios tiene la publicación?

50 respuestas

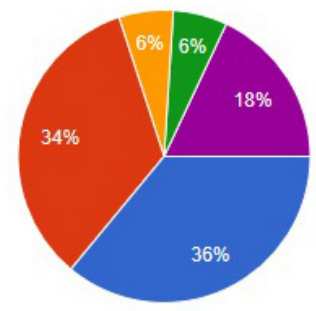

Ninguno

- De 1 a 5

De 6 a 10

De 11 a 15

- Más de 16

Las temáticas sobre la constitución reflejadas en los comentarios son:

50 respuestas

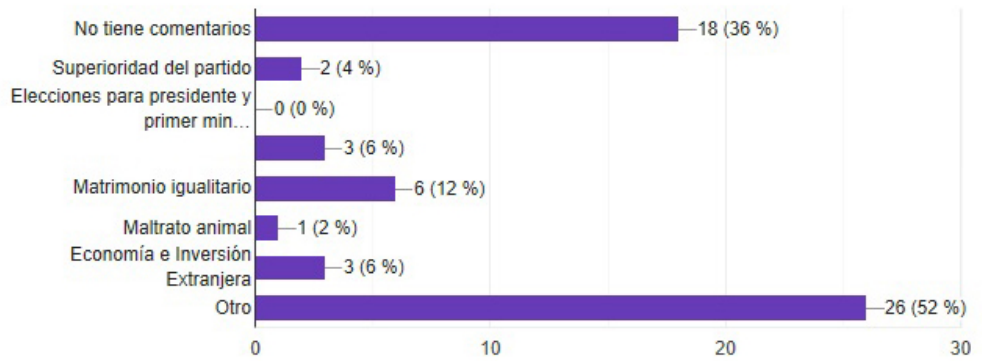

Similarly, we used an open-ended question scheme to reflect the other issues encountered during the application of the survey, which evidenced high frequencies referring to other issues not included in the proposed list.

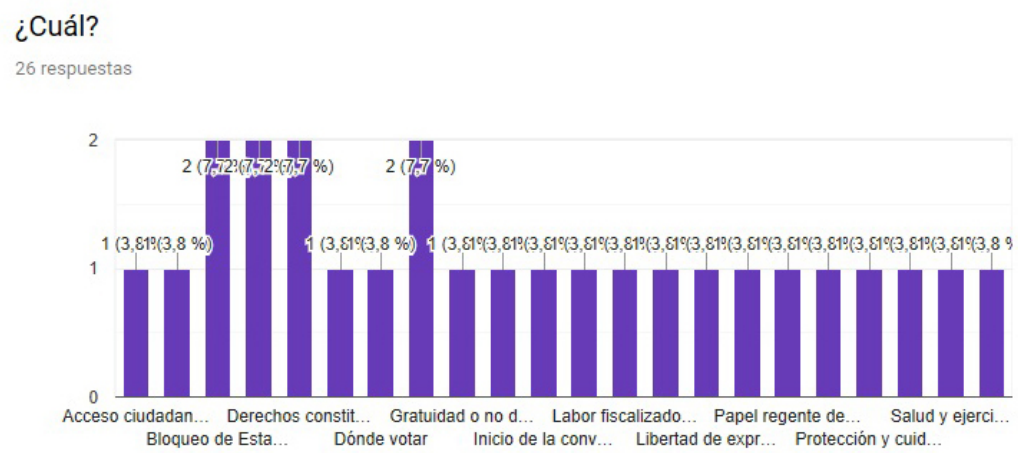

For these purposes, the referendum of February 24, 2019 was the starting point for new visualizations of the Cuban digital public sphere. In a context where the coordinates go towards the mobilization of the revolutionary bases, and Tania Bruguera ${ }^{4}$ defines it well: "today, something is beginning to change in Cuba, but it is not the government, it is the people who have decided not to wait any longer and make themselves felt (...) as citizens with rights" (2019, p. 2).

\section{Conclusions}

From the data found above, we can express the following conclusions:

- Readers/internet users showed a greater presence, thanks to their comments, on the Cubadebate news platform, as it has a greater number of comments. On the OnCuba platform, however, there were more debates among the readers.

- In no case was there a response from the news platform, nor from its editors, which reflected the null presence of the media within the discussion platform.

- The topics of debate have many similarities in both platforms, but the way of presenting them is substantially

${ }^{4}$ She is an internationally recognized Cuban artist for her provocative proposals on power and social controls. 
distanced, because OnCuba is dedicated to a more reflective journalism and Cubadebate are more news.

- The most debated topics corresponded to what the article proposed, showing a coherence between the introduced topic and what the readers were talking about. In this way, several themes were inserted that were incorporated according to the context that motivated the participation.

- There is citizen participation in the Cuban digital public sphere, which is reflected through the comments analyzed through the two news platforms.

- From the perspective of the authoritarian public sphere, we can appreciate the dominance of the homogenization of the preferred, consumed and desired contents, although some preferences are still maintained thanks to the plurality of the online media perspective.

\section{BIBLIOGRAPHY}

Adut, A. (2012). A Theory of the Public Sphere. Sociological Theory, 30(4), pp. 238-262.

Aguirre, B. (2002) Social Control in Cuba. Latin American Politics and Society 44(2), 67-98.

Álvarez, C. (27 de febrero de 2019). Los cubanos hemos empezado a vivir en la Cuba del futuro sin pedir permiso. The New York Times. Recuperado de https://www.nytimes.com/es/2019/02/27/cuba-constitucion/?smid=fb-sharees\&fbclid=IwAR1gP5aemR-qY05sCwojpHs6Rh8WRQOwlGQbA0pl81 Klw18zW5bf-oswbWU

Baiocchi, G. (2003). Emergent Public Spheres: Talking Politics in Participatory Governance. American Sociological Review 68, 52-74.

Blumler J. \& Gurevitch, M. (1995). Linkages between mass media and politics. En Curran, J., Gurevitch, M. \& Woollacot, J. (Eds.). Mass Communication and Society. Londres, Reino Unido: Edward Arnold.

Bruguera, T. (22 de febrero de 2019). Los cubanos hemos empezado a vivir en la Cuba del futuro sin pedir permiso. The New York Times. Recuperado de https://www.nytimes.com/es/2019/02/22/cuba-censura/?rref=collection\%2Fsectioncoll ection $\% 2$ Fnyt-es\&action $=$ click\& contentCollection $=$ revolucion $-60 \&$ region $=$ stream\&module $=$ stream $u$ unit\&version $=$ late st\&contentPlacement $=3 \&$ pgtype $=$ collection

Castells, M. (2009). Comunicación y poder. Madrid, España: Alianza Editorial.

Castells, M. (2012). Redes de indignación y esperanza. Los movimientos sociales en la era de Internet. Madrid, España: Alianza Editorial.

Chaguaceda, A. \& González, L. (2015). Participación comunitaria y gobiernos locales en Cuba. La experiencia de los Consejos Populares y el impacto de las reformas de Raúl Castro. Revista Espiral, 22(63).

Dahlgren, P. (2005). Internet, esferas públicas y política. Comunicación: Dispersión y deliberación, Comunicación política, 22(2), 147-162, DOI: 10.1080 / 10584600590933160

Diario Las Américas (12 de enero 2019). \#YoVotoSí, \#YoVotoNo: Los cubanos, las redes sociales y el referendo constitucional. Diario Las Américas. Recuperado de: https://www.diariolasamericas.com/america-latina/yovotosiyovotono-los-cubanos-las-redes-sociales-y-el-referendo-constitucional-n4169903

Dukalskis, A. (2017). The Authoritarian Public Sphere. Legitimation and Autocratic Powerin North Korea, Burma and China. Nueva York, Estados Unidos: Routledge.

Eliasoph, N. (1998). Avoiding Politics: How Americans Produce Apathy in Everyday Life. New York, Estados Unidos: Cambridge

El País (26 de febrero de 2019). Cuba aprueba en referéndum una nueva Constitución. El País. Recuperado de: https://elpais.com/internacional/2019/02/26/america/1551137483 447532.html

Evans, M. (2012). Who Wants a Deliberative Public Sphere? Sociological Forum, 27 (4), 872-895.

Ferree, M., Gamson, W., Gerhards, J. \& Rucht, D. (2002). Four models of the public sphere in modern democracies. Theory and Society, 31, 289-324.

Habermas, J. (2009a). Medios, mercados y consumidores: la prensa seria como espina dorsal de la esfera pública política. Madrid, España: Trotta.

Habermas, J. (2009b). ¿Tiene aún la democracia una dimensión epistémica? Investigación empírica y teoría normativa. 
Madrid, España: Trotta.

Habermas, J. (2014). Prefacios a las ediciones de 1990 y 1960. En Historia y crítica de la opinión publica (1-39). Barcelona, España: Gustavo Gil.

IFE. (2014). Informe País sobre la calidad de la ciudadanía en México. Ciudad de México, México: Instituto Federal Electoral.

Mughan, A. \& Gunther, R. (2000). The Media in democratic and no democratic regimes: a multilevel perspective. Democracy and the Media, Cambridge UP., 1-27. Recuperado de https://books.google.es/books?hl=en\&lr=\&id=Xf CDTe5s9ngC\&oi $=$ fnd\&pg $=$ PA $1 \& d q=$ The + Media $+\mathrm{in}+$ democratic + and + no + democratic + regimes $:+a+$ multinivel + pe

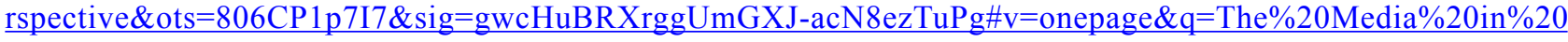
democratic $\% 20$ and $\% 20$ no $\% 20$ democratic $\% 20$ regimes $\% 3 \mathrm{~A} \% 20 \mathrm{a} \% 20$ multinivel $\% 20$ perspective $\& \mathrm{f}=$ false

OnCuba (29 de diciembre de 2018). Cuba y sus cambios en internet. Revista OnCuba. Recuperado de https://oncubanews.com/cuba/cuba-y-sus-cambios-en-internet/

Ortega, A. (2019). Gobernanza digital: ¿hacia una nueva utopía? Revista Telos, 110, 10-15.

Ramírez, E., Salgueiro, A., \& Sá, L. (2018). Cuba a debate: la politización de conversaciones online sobre migración en el sitio Cubadebate. Revista Razón y Palabra, 22(3), 418-438.

Rabotnikof, N. (2008). Discutiendo lo público en México. En Merino, M. (2008). ¿Qué tan público es el espacio público en México? (25-56). Ciudad de México, México: CONACULTA.

RTVE.ES/Agencias (25 de febrero de 2019). Cuba refrenda la nueva Constitución con una amplia mayoría, aunque el voto del descontento marca máximos. RTVE. Recuperado de: http://www.rtve.es/noticias/20190226/cuba-refrendanueva-constitucion-amplia-mayoria-aunque-voto-del-descontento-marca-maximos/1890441.shtml

Sermeño, A. (2013). Razón y espacio público en la democracia deliberativa. Una perspectiva habermasiana. Andamios, $10(23), 205-231$.

Taylor, Ch. (2004). Modern Social Imaginaries. NC: Duke University.

We Are Social (2019). Digital in 2019. Recuperado de https://wearesocial.com/uk/digital-2019

Welp, Y. (21 de febrero de 2019). Cuba, ¿Otra vez sopa? Agenda_Pública El País. Recuperado de https://agendapublica. elpais.com/cuba-otra-vez-sopa/

Zelizer, B. \& Allan, S. (2002). Journalism after september 11. Londres-Nueva York, Reino Unido-Estados Unidos: Routledge.

\section{APPENDIXES}

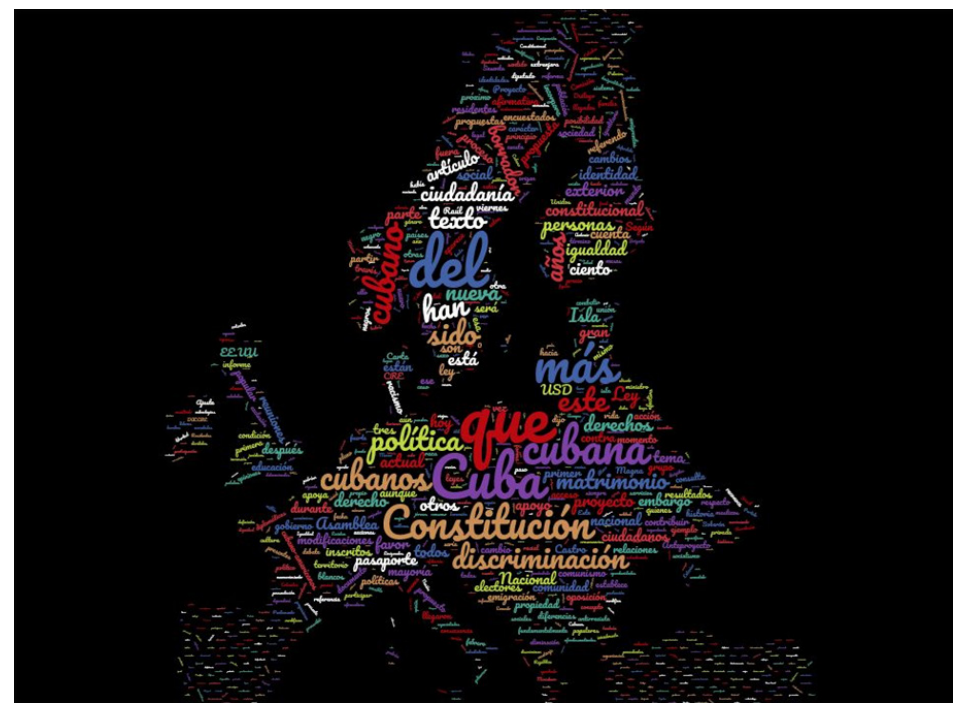

Graph 1. Most used words during the comments to the texts that refer to the Cuban constitution, by the news platform Cubadebate. Source: Written by the author. 

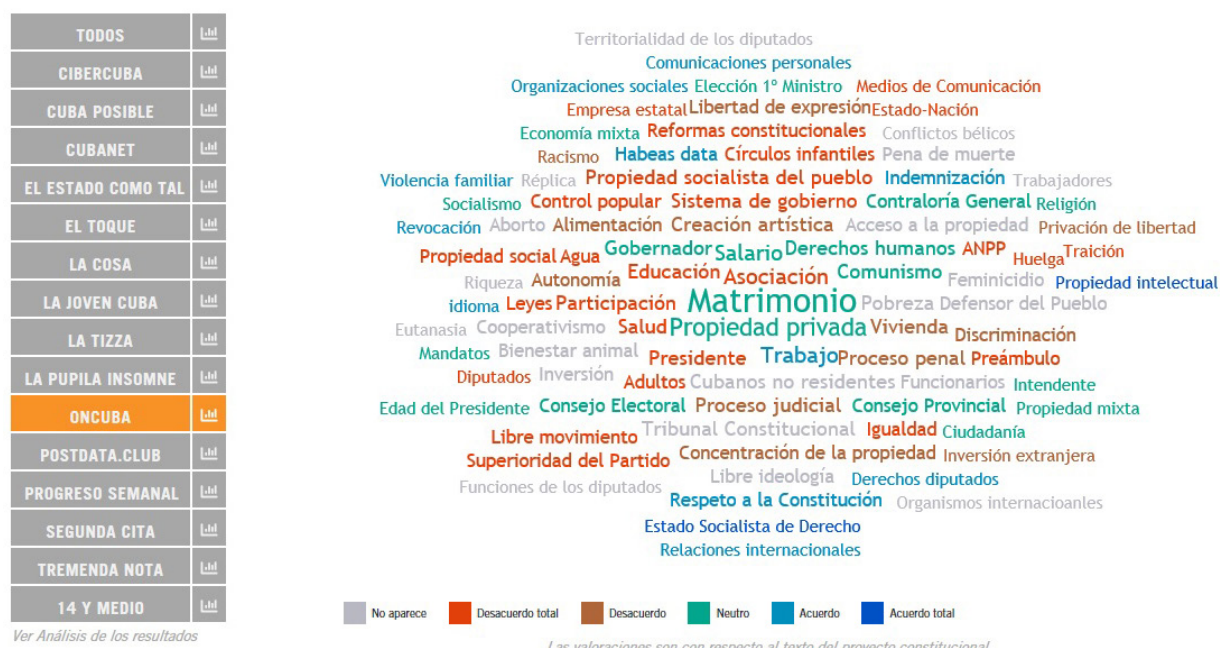

Graph 2. Most used words during the comments to the texts that refer to the Cuban constitution, by the OnCuba news platform. Source: El Toque.

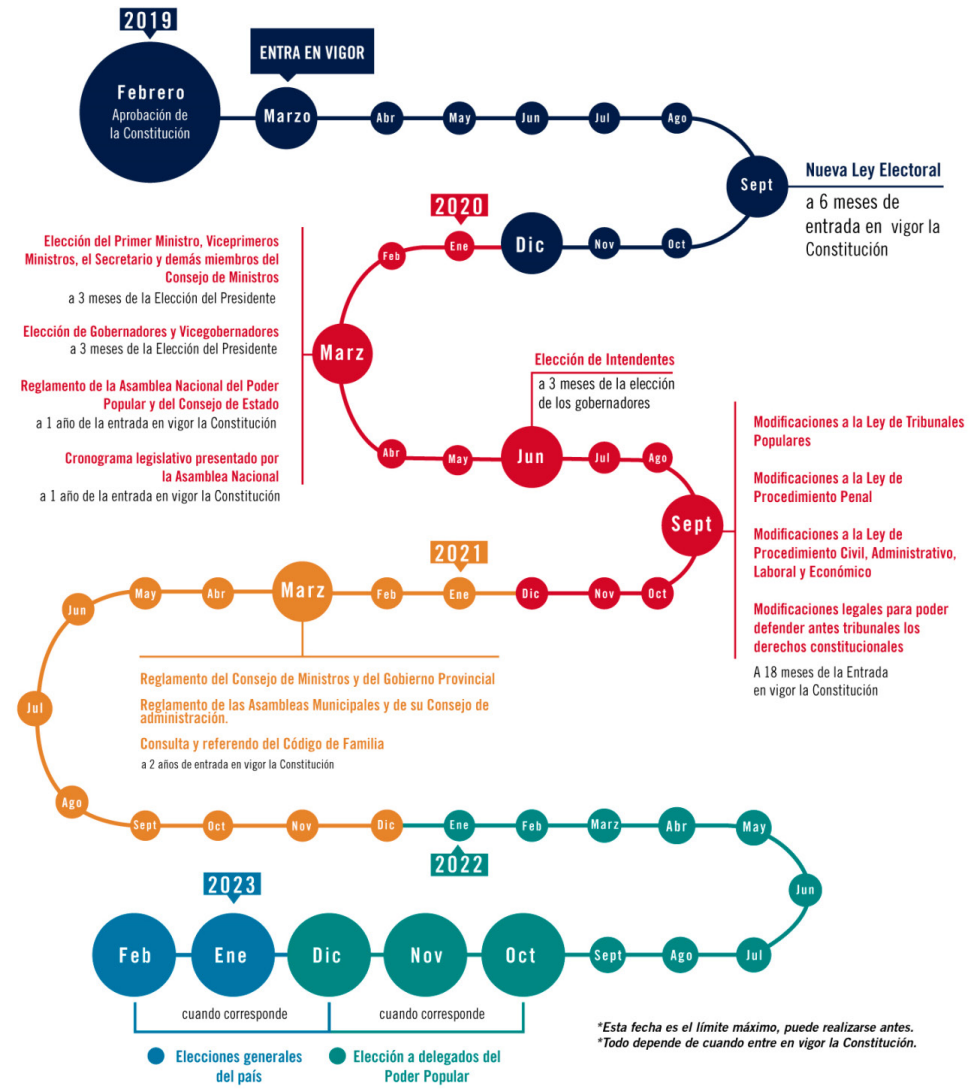

Graph 3. Process that continues after the approval of the new Cuban Constitution. Source: El Toque. 